\title{
Module Development of Tolerant Character Based on Local Wisdom for Elementary Teacher in Godean District, Sleman
}

\author{
Anwar Senen, Safitri Yosita Ratri, and Fathurrohman
}

Faculty of Education, Yogyakarta State University, Yogyakarta, Indonesia

\section{Abstract}

The aim of this research is to 1) develop thematic learning content especially in Elementary School which focuses on tolerant characters based on local wisdom 2) develop thematic learning model that accommodate tolerant characters based on local wisdom in the planning and implementing learning aspects. Module is developed for teachers to be able to teach tolerant characters based on local wisdom to the participants. The development of learning models of tolerant characters based on local wisdom is intended to guide teachers in implementing thematic learning that focuses on students' tolerant character based on local wisdom, especially local Javanese wisdom.

Corresponding Author: Anwar Senen

Received: 2 May 2019 Accepted: 19 June 2019 Published: 3 July 2019

Publishing services provided by Knowledge E

(c) Anwar Senen et al. This article is distributed under the terms of the Creative Commons Attribution License, which permits unrestricted use and redistribution provided that the original author and source are credited.

Selection and Peer-review under the responsibility of the ICMEd Conference Committee. This research used Research and Development method that consists of two stages, namely: (1) The preliminary stage is the stage of research and information gathering concerning the learning of tolerant characters based on local wisdom among Elementary School students, (2)The planning stage of learning content of tolerant character based on local wisdom as the development of the initial product form. Elementary Schools in Godean District, Sleman, in the Special Region of Yogyakarta in this research are the subject. Data validity uses expert judgment techniques and quantitative analysis with descriptive analysis techniques.

The results showed that "Integrative Thematic Module Based on Javanese Local Wisdom to Develop Tolerant Characters" was suitable to be used as one of the learning resources used by teachers to carry out learning, especially in the Social Science Theme in grade $\mathrm{V}$.

Keywords: teacher's module, tolerance character, local wisdom

\section{Introduction}

This development research was carried out to obtain a model of the effectiveness level of teacher coaching to improve social competence in the context of character building among elementary school students who could provide the right information for the education office and optimally beneficial for the improvement of elementary school teachers' social competence programs. The results are expected to be a model 
to improve teachers' social competence and provide accurate information in terms of content, capacity, format, and time for training.

We need to realize that in the life of the nation and the state of Indonesia, there are a variety of ethnicities, cultures, religions, and languages. From these diverse sociocultural backgrounds, our country is known for its multicultural life. The multicultural community life will be able to run harmoniously and strongly if every citizen of the community respects and upholds the cultural values that are believed by each component of the community. Between the components of society one cannot feel higher or feel superior to the other components of society. Primordialism which makes certain groups feel that they have advantages and the others feel marginalized must be eliminated to build a strong and harmonious national and state life. The motto of Bhineka Tunggal Ika and Pancasila in this case needs to be reminded to the younger generation (students) to be used as spirit and guidelines in daily life in the life of the nation and state.

This spirit of tolerance needs to be nurtured back to the younger generation. Schools have strategic opportunities to foster a spirit of tolerance in the nation in order to create a strong and harmonious life.In this case, the teachers plays a big role in building a tolerance for the younger generation (students) since the material allows the teacher to contribute through the material with cultural themes.

Elementary School teachers have a share in fortifying the younger generation (students) from influence of outside culture that is not in accordance with the soul and spirit of national and state life based on local cultural values. Teachers must be able to uphold the fundamental character of humanity. Those basic principles of humanity consist of justice, equality, wisdom, and diversity. In diversity there are various forms of pluralism, such as religion, ethnic, language, customs and so on. Justice and equality apply to the various form of pluralism. Teachers should be able to build a national identity, among others through the approach of local wisdom to lead to harmonious and resilient future.

The problem is, from the preliminary study results in elementaryschool in Sleman Regency from three regions of UPT Pendidikan as research sample namely UPT Pendidikan in Minggir District, GodeanDistrict, and Depok District it is noted that:

1. There are teachers that not presented the thematic material based on local Javanese wisdom, especially to develop tolerance.

2. The learning presented still emphasizes cognitive goals.

3. The development of affective aspects which is manifested in the development of moral awareness and student behavior is still very lacking. 
4. In general, teachers do not understand the learning strategy with a contextual approach, especially the contextual approach based on local Javanese wisdom.

5. In general, teachers have not utilized the social environment of students as learning resources in a contextual approach.

6. The evaluation that was developed did not measure the attitudes.

7. Not yet developing local Javanese wisdom, especially in learning

Based on the background of the problems described above, the problem of this research was formulated as follows.

1. How to equip the concept of tolerant character based on local wisdom on elementary teachers in thematic learning in elementary school?

2. How to develop a tolerant character module based on local wisdom on aspects of planning and implementation?

Based on the formulation of the problem above, the purpose of this research are as follows:

1. To develop thematic learning content, especially in elementary schools which focus on tolerant characters based on local wisdom.

2. To develop a thematic learning model that accommodates tolerant characters based on local wisdom on aspects of planning and implementing learning.

\section{Literature Review}

\subsection{Tolerant character in nation and state life}

UNESCO (1994: 15) provides an explanation about tolerance as follows:

"Tolerance is not an end but a means; it is the minimal essential quality of social relations that eschew violence and coercion. Without tolerance, peace is not possible. With tolerance, panoply of positive human and social possibilities can be pursued, including the evolution of a culture of peace".

It can be interpreted, that tolerance is not the final road but tolerance as a middle way; tolerance is an essential minimum measure of a social relationship capable of resisting violence. Without tolerance, peace cannot be realized. With tolerance, the 
strength of the relationship between humans can be achieved, including evolution in creating a culture of peace. Tolerance as a social condition is closely related to a widely held attitude among the community. As part of the assessment carried out by the community, tolerance will be considered the same as a trait desired by society in their lives. Therefore, the community will educate its citizens to assess and train tolerance.

In the context of nation and state life in Indonesia with motto of Bhineka Tunggal Ika, in fact it has implied how important tolerance to be used as a guidance of life. Indonesia with various backgrounds is one. To maintain this "unity" tolerance is needed in the nation and state life. Minister of Education and Culture, Muh Nuh, (http://berita. upi.edu/2011/10/31) in his speech in UNESCO meeting in Paris, France stated that "With understanding the meaning of tolerance, Indonesian can prevent racial, ethnical, cultural and spiritual conflicts to build a peaceful life and simultaneously, at the same time can build a creative community improve productivity". Next, he stated that "The importance of this tolerance and honesty is a character education needs that becomes the part of school curriculum which is embedded in every subject and taught at all stages of education, especially in the early stages."

\subsection{Local wisdom in the middle of diversity}

The definition of local wisdom (local genius) as a whole can be considered equal to Culture Identitythat interpreted as nation's culture identity, which result in the nation concerned become more able to absorb and process the influence of culture outside if its territory, in accordance with its personal character and needs (Soebadio, 1986: 18-25).

The definition of local wisdom according to Sedyawati (1986: 186-192) can be divided into two definitions, namely:

1. All values, concepts and technology that a nation has before it receive foreign influence.

2. The power possessed by a nation to absorb, interpret, change and create as long as there is "foreign influence".

Local wisdom can also be defined as Local Development, which is a local development whose direction is towards change. Local wisdom and local development in Indonesian society developed after cultural contact or acculturation with other cultures, especially those coming from India (Hindu culture). However,the original elements in the Pre-Hindu Age also had important decisive motive, so that the original elements 
were not lost. The local wisdom of the Indonesian people is the ability to absorb foreign cultures that come selectively, this means that it is adjusted to the local atmosphere and conditions (Atmodjo, 1986: 47).

Efforts to socialize or to introduce local potential can be made through the education process because according to Parsons, education has a function of socialization and selection. Socialization in education includes aspects of value, cognition and motoric. Between the three aspects,Parsons prioritizes value, because consensus on value is a factor that is required for the emergence and maintenance of social integration. Through socialization, community cultural values are transformed into values that are internalized by individual community members. According to Parsons, society can be grouped into three subsystems, namely cultural systems, social systems, and personality systems. A cultural system consists of value, norms, knowledge and life belief and conviction that are shared together. In a social system, there is role structure that is behavior carried out by individuals according to their social status. In personality system, individuals have interests that are born or formed during the socialization process for themselves. In the society there is also a hierarchy of supervision as follows: Cultures control the community, and community controls its citizen individually. Meanwhile, in the other hand, there are resistances, which is the behaviour of individuals in realizing and maintaining social norms and cultural value of society (Adiwikarta, 1988: 17).

\subsection{Thematic learning}

Thematic learning is integrated learning using a theme as a way to associate several subjects so that it can give meaning to students (Depdiknas, 2006).

Thematic learning emphasizes the active involvement of students in the learning process so that the students are trained to understand various concepts and have the experience to find the meaning of learning with teacher's guidance. This thematic approach that emphasize in students activeness is in accordance with modern learning approach, where students actively learning in the framework of finding the learning means through direct experience in understanding the concept of teaching material meanwhile the teacher act as facilitator, dynamist, and motivator.

The purpose of thematic learning applied in the learning process is to provide students with an in-depth and memorable understanding so that they have a deep meaning on the teaching material presented by the teacher. Teaching materials can also be developed by teachers based on basic competencies adapted to real experiences in the lives of students' every day. In terms of teaching materials, thematic learning 
allows the effectiveness of the allocation of learning time because it can avoid teaching materials that have similarities in discussion in each subject.

In education in the learning process in schools, the values that exist in local wisdom have a strategic role in their participation in counteracting negative cultural influences that come from outside or from within. This can be happen because the values of local wisdom provide a good and positive educational formulation on the moral side of students as a basis for behavior-attitude in responseto the dynamic of life that is full of challenges in the current global era.

\section{Material \& Methodology}

\subsection{Research approach}

The research method used in this study isResearch and Development. According to Borg and Gall (1989:782), what is meant by the research and development model is "a process used to develops and validate educational product". In 'research based development', in which appears as a model and aims to improve the quality of education.In this research,Research and Development used to produce tolerant character modules based on local wisdom for elementary school teachers. In this Research and Developmentwas reduced into three (3) stages out of 10 steps, which are: (1) The preliminary stage is the stage of research and information gathering concerning the learning of tolerant characters based on local wisdom among elementary school students, (2) The planning stage of the learning content of the tolerant character based on local wisdom as the development of the initial product form, (3) Trial, evaluation and revision stage through implementation of preliminary trials and small-scale trials.

\subsection{Research subject and object}

In the trial of the model, it involves 6 teachers with subjects obtained by purposive sampling. Meanwhile, the object in this study is a tolerant character module based on local wisdom for elementary school teachers.

\subsection{Research subject and location}

This research was carried out in elementary schools in the Godean District, Sleman Regency, DIY. 


\subsection{Data collection technique}

Data collection techniques are carried out based on the research objectives of each stage. At the preparation stage with the validation of material experts and media experts with questionnaire instruments. After that, test the readability of the three teachers in the form of a questionnaire. Small group trials on six teachers with data collection techniques in the form of questionnaire instruments were done to reveal how readability level and usefulness level for the implementation of tolerant character learning based on local wisdom.

\subsection{Data collection instrument}

The type of instrument used in this study is a questionnaire. The questionnaire is composed of three types according to the role and position of respondents in this development research. The research instrument in the form of questionnaire is arranged based on the grids that have been developed and arranged using a Likert scale. The questionnaires are (1) questionnaire for material experts, (2) questionnaire for media experts and (3) questionnaire for teachers. The first type of questionnaire is used to obtain data about the quality of the material, the appearance, and learning process and is filled by someone who is an expert in the field of material being developed. The second questionnaire was used to obtain data about the technical quality of the product produced. The third questionnaire was used to obtain data about the quality of teaching materials from the results of the trials with the teachers.

\section{Results and Discussion}

\subsection{Module evaluation by material and media experts}

The assessment from the material experts is carried out first before the assessment from media experts. As a reviewer for this module material is Dr. Wuri Wuryandani, M.Pd, one of the expert lecturers in the field of character education in the Department of Elementary School Education, FIP UNY. Validation by material experts has been done twice which is classified in three aspects, namely learning, content, and local wisdom. In learning section, there is a note about the scope and clarity of the material that there are no module usage instructions. 
The scope of the material is also recommended to not take sides with one religion or belief but must be national or general. The material expert said that there were still written sentences that did not use standard language and the writing of sentences that matched the EYD using SPOK. One paragraph of one story is to be used as a principle in writing a description in one paragraph and making continuity between paragraphs.

For material, the average score is sufficient; she suggested that the content in learning activities adjust the real situation of students' every day and not fiction. Also, the module contents are supplemented by student learning activities as a real implementation of tolerant attitudes, namely with an addition of the "Ayo Kerja bakti" column. For local wisdom, there is a note that indicators of learning that accommodate norm-based social attitudes in society, for example respect for parents is lacking. In the module, local wisdom is still limited to discussing cooperation in the community but has not accommodated the attitudes of students individually such as courtesy and respect for older people as is the norm in Javanese culture.

The media expert for the product of this research is Mr. Sungkono, M.Pd., one of the lecturers in the Department of Educational Technology, FIP UNY. The validation is done twice consisting of clarity of module title, attractiveness of cover design, attractiveness of color usage, suitability of color combinations with other visuals/graphics, attractiveness of image usage, suitability of font type selection, text readability, interesting layout, and strength or module durability. The input and suggestions for improvement are as follows:

\section{Cover Page}

There are numbers of things to improve in the cover page:

(a) Light blue need to be changed to bright blue to make it more attractive but still not too flashy.

(b) The theme and sub-theme are not Tema 3 Subtema 1 but it should be Tema 3 Kerukunan dalam Masyarakat Subtema 1 Hidup Rukun.

(c) The phrase Buku Siswa is placed in the middle.

(d) The pictures need to be replaced, pictures of the child working in the school yard are replaced with pictures of the students playing games with the background of the school building, pictures of electricity and animals that seem to be replaced by pictures of children cleaning the school yard.

\section{Color content}


On the content page, the background color changes that is white to bright blue. In the learning activities section, the problem column changes from blue to bright yellow

\section{Introduction}

In the introduction, there are additions that previously did not exist, for example:

(a) The writing of Kompetensi Dasar Ke-1 and Ke-2

(b) The writing of Kompetensi Dasar Ke-3 and Ke-4

(c) Indicator

(d) Module Usage Instruction

4. Content

There are several things that are needs to be improved in Chapter I:

(a) Writing the previous page number on the lower left side to the bottom right.

(b) Reading illustrations that were previously made in one page are inserted following paragraphs.

\section{Game Illustration and Gundul-gundul Pacul Song}

In the previous module, the students' illustrations were too dense to be changed to become more tenuous.

\section{Learning Activities in Playing Kasti}

The activity of students learning kasti games in the form of paragraphs changed into instructions in the form of game steps.

After going through the revision, the module is re-validated by the material expert and there is a note that the source should not be included in the module script but written in the Bibliography. Based on the data of material validation results obtained an average score of 2.9 (included in the good category) in the first validation and to 3.6 (included in the excellent category) with the conclusion of the module is feasible to be tested without revision.

The results of the first validation of the Media Expert based on the instrument are as follows. From these data on indicators of attractiveness of the cover design, suitability of font size, and strength or durability of the module is included in the sufficient category. For criteria for clarity of module title, attractiveness of color usage, suitability of font type selection, readability of text, and interesting layout are included in good category. The 
suitability indicator of color combinations and the attractiveness of the use of images are in very good categories. The average score for this first validation is 2.9 (included in the good category) with conclusions worth testing with revision.

The results of the second validation after going through revision, the indicator gets very good assessment value except on the indicator of the attractiveness of the use of color and the suitability of the selection of font sizes that fall into good category. Suggestions for improvement are the need for careful writing, for example, the word TV or Tv or tv needs to be consecrated and there is a less contrasting color section, which is a white blend that is less suitable for yellow. The second average score for validation is 3.8 (included in very good category) with conclusions worth testing with no revisions. Thus, an increase in scores on media expert instruments is 1.1 points.

\subsection{Description of FGD results with the teacher - User module readability}

After going through the validation from the material experts and media experts, the next step was to conduct an FGD (Focus Group Discussion) with elementary teachers at the Sewon District UPT. Due to time constraints, the FGD can only be done with three teachers. Assessment consists of three aspects, namely the appearance, presentation of material, and the learning process which is divided into 12 indicators. For the aspect of display three teachers stated the appearance was very good. For the aspect of material presentation, one teacher stated that the presentation of material was good and two teachers stated that the presentation of the material was very good. As for the aspect of the learning process, one teachers stated that the learning process was good and the teacher stated that the learning process was very good

The suggestions for improvement from the teachers are:

1. Illustrations on the cover are not large enough.

2. Local cultural wisdom in the adverts need to be added because Godean is not only a source of geplak but also eels and fish products.

\subsection{Module assessment by material and media experts}

The product produced from this study is an Integrative Thematic Module Based on Javanese Local Wisdom to Develop Tolerant Characters for Grade V Elementary School Students. The product has gone through a review stage by the Material Experts, Media 
Experts, and Readability Tests from Some Elementary Teachers in Godean District. From the above assessment, product assessment values can be summarized in Table 1 and Table 2 below.

TABLE 1: Assessment of Modules from Material Experts and Media Experts.

\begin{tabular}{|l|c|c|c|}
\hline Assessor & Stage I & Stage II & Improvement \\
\hline Material expert & 3,6 (good) & 4,5 (excellent) & 0,9 \\
\hline Media expert & 3,6 (good) & 4,7 (excellent) & 1,1 \\
\hline
\end{tabular}

TABLE 2: Module Readability by Elementary Teachers.

\begin{tabular}{|l|c|c|c|}
\hline Assessor & Appearance & $\begin{array}{c}\text { Presentation of } \\
\text { Material }\end{array}$ & Learning Process \\
\hline Teacher 1 & 4,5 (very good) & 4,0 (good) & 3,7 (good) \\
\hline Teacher2 & 4,3 (very good) & 4,3 (very good) & 3,9 (good) \\
\hline Teacher3 & 4,7 (very good) & 4,2 (very good) & 4,2 (very good) \\
\hline
\end{tabular}

The module product that is prepared will be used as a learning resource for elementary school students in grade V. After going through the validation phase of material experts, media experts and assessors from elementary school teachers in Godean District, the product was revised according to the experts' suggestions. Based on the results of the experts' scores, the product can be categorized as a module that is feasible to be tested. Therefore, as a further plan, the product will be tested in the next semester for fifth-grade students in elementary school in the UPT of Godean District, Sleman DIY.

\section{Conclusion}

Based on the results and discussion, it can be concluded that the development of teaching materials in the form of books with the title "Integrative Thematic Module Based on Javanese Local Wisdom to Develop Tolerant Characters" is feasible to be used as one of the learning resources. It means that teachers can use it to carry out learning especially in the Social Science Theme in grade V.

The development of this module is through material validation tests, media validation tests, and elementary school teacher trials in the Godean District, Sleman Regency. In the material validation obtained an average score of 2.9 (sufficient category) in the first test and an average of 3.6 (good category) in the second test, while the validation test by media experts obtained an average score of 2.9 (good category) in the first test and 3.8 (good category) in the second validation test. Furthermore, the results of the assessment of user readability is an average score of 4.5 (very good category), 
presentation of material with an average score of 4.2 (very good category), and learning process with an average score of 3.9 (good category). Thus, this module is declared eligible for use by grade $\mathrm{V}$ of Elementary School students.

According to expert material advice, the module also needs to be equipped with an answer key for each evaluation activity. The answer key is placed as an attachment after the Bibliography. After going through the revision, the module is re-validated by the material expert and there is a note that the source should not be included in the module script but written in the Bibliography. Based on the data of material validation, the results obtained an average score of 2.9 (included in the good category) in the first validation with a conclusion worthy to be tested with revision. In the second validation the average score becomes 3.6 (included in the very good category) with the conclusion the module is worthy to be tested without revision.

\section{References}

[1] Adiwikarta, S. (1988). Sosiologi Pendidikan: Isu dan Hipotesis tentang Hubungan Pendidikan dengan Masyarakat. Jakarta: PPLPTK Dirjend Dikti, Depdikbud.

[2] Atmodjo, M.M.S.K. (1986). "Pengertian Kearifan Lokal dan Relevansinya dalam Modernisasi" dalam Ayatrohaedi, penyunting (1986).Kepribadian Budaya Bangsa (Local Genius). Jakarta: Dunia Pustaka Jaya. Hal 46-53.

[3] Eko Putro Widoyoko. (2010). Evaluasi Program Pembelajaran. Yogyakarta: Pustaka Pelajar.

[4] Santosa, Iman Budi. 2012. Nasihat Hidup Orang Jawa. Yogyakarta: Diva Press.

[5] Sedyawati. (1986). "Lokal Genius dalam Kesenian Indonesia" dalam Ayatrohaedi, penyunting (1986). Kepribadian Budaya Bangsa (Local Genius). Jakarta: Dunia Pustaka Jaya. Hal. 186-192

[6] Soebadio. (1986). "Lokal Genius dalam Kesenian Indonesia" dalam Ayatrohaedi, penyunting (1986). Kepribadian Budaya Bangsa (Local Genius). Jakarta: Dunia Pustaka Jaya. Hal. 18-25.

[7] UNESCO APNIEVE. (2000). Belajar Untuk Hidup Bersama dalam Damai dan Harmoni. Kantor Prinsipal Unesco untuk Kawasan Asia Pasifik, Bangkok \& Universitas Pendidikan Indonesia.

[8] UNESCO (1994).Tolerance: The Threshold of Peace (Preliminary version). Paris: UNESCO. 